\title{
Factor XIII Deficiency
}

National Cancer Institute

\section{Source}

National Cancer Institute. Factor XIII Deficiency. NCI Thesaurus. Code C131633.

A coagulation disorder characterized by the partial or complete absence of factor XIII activity in the blood. 